\title{
Particulate Matter Source Contributions for Raipur-Durg-Bhilai Region of Chhattisgarh, India
}

\author{
Sarath K. Guttikunda ${ }^{1,2^{*}}$, Pallavi Pant ${ }^{3}$, K.A. Nishadh ${ }^{1}$, Puja Jawahar ${ }^{1}$ \\ ${ }^{1}$ Urban Emissions, New Delhi, India \\ ${ }^{2}$ Division of Atmospheric Sciences, Desert Research Institute, Reno, NV 89512, USA \\ ${ }^{3}$ Department of Environmental Health Sciences, University of Massachusetts, Amherst, MA 01003, USA
}

\begin{abstract}
In Chhattisgarh, Raipur-Durg-Bhilai (RDB) tri-city area hosts the new administrative capital of the state, interconnected by an expressway forming the industrial corridor and is one of the largest steel manufacturing hubs in India. Between 1998 and 2016, the satellite and global model data derived concentrations show a 50\% increase in the overall $\mathrm{PM}_{2.5}$ pollution in the region. The average $\mathrm{PM}_{10}$ concentration measured at commercial, industrial, and residential monitoring stations is 125 $\pm 52 \mu \mathrm{g} \mathrm{m}^{-3}$ in 2015. None of the stations currently measure $\mathrm{PM}_{2.5}$. The annual average $\mathrm{PM}_{10}$ concentrations in 2011 is 175 $\pm 110 \mu \mathrm{g} \mathrm{m}^{-3}$, which translates to $28 \%$ improvement in 5 years. A multiple pollutant emissions inventory was established for this urban airshed (extending $60 \mathrm{~km} \times 30 \mathrm{~km}$ ), with annual estimates of 41,500 tons of $\mathrm{PM}_{2.5}, 59,650$ tons of $\mathrm{PM}_{10}$, 7,600 tons of $\mathrm{SO}_{2}, 67,000$ tons of $\mathrm{NO}_{\mathrm{x}}, 163,300$ tons of $\mathrm{CO}, 118,150$ tons of NMVOCs, and 3.1 million tons of $\mathrm{CO}_{2}$ for 2015, and further projected to 2030 under business as usual conditions. The ambient source contributions were calculated using WRF-CAMx chemical transport modeling system, highlighting the heavy industries (mostly steel) (23\%), followed by transport (including on road dust) (29\%), domestic cooking and heating (12\%), open waste burning (6\%), as the key air pollution sources in the urban area. The city has an estimated $26 \%$ of the ambient annual $\mathrm{PM}_{2.5}$ pollution originating outside the urban airshed - this contribution is mostly coming from the coal-fired power plants, large (metal and non-metal processing) industries, and brick kilns located outside the urban airshed and seasonal open biomass fires.
\end{abstract}

Keywords: $\mathrm{PM}_{2.5}$; Particulate pollution; Raipur; Durg-Bhilai; India; WRF-CAM ${ }_{\mathrm{x}}$; Emissions inventory; Dispersion modeling; Source apportionment.

\section{INTRODUCTION}

Much of air quality research in India has focused on large metropolitan cities and the cities in the Indo-Gangetic Plains (Guttikunda et al., 2014). There is limited information available in terms of air quality levels and limited research on source contributions, associated health impacts, and environmental damages in Central India, which harbors the largest industrial hubs, coal-fired power plants, and mining (Pant and Harrison, 2012; Guttikunda et al., 2014; Venkatraman et al., 2018). In Central India, Chhattisgarh is rich in a variety of mineral resources including coal, iron ore, limestone, tin and bauxite, and by extension, is one of the national hubs for mining and ore-processing industries. Industries contribute nearly $30 \%$ of the state's total GDP and more than $20 \%$ of the state's forest land has been converted into industrial land (Joshi et al., 2008). In addition,

\footnotetext{
${ }^{*}$ Corresponding author.

E-mail address: sguttikunda@gmail.com
}

it is one of the major wheat producing states, leads in coal production (22.6\% of national), and steel/sponge iron production (19.8\% of national) (Burney and Ramanathan, 2014). Under the state's industrial policy plan (2014-19), there has been a concerted effort to improve ease of business through a variety of fiscal and policy incentives.

In Chhattisgarh, Raipur-Durg-Bhilai (RDB) tri-city area hosts the new administrative capital of the state, interconnected by an expressway forming the industrial corridor, and located on the banks of the Mahanadi River between the Chota Nagpur in the North and Deccan Plateau in the South. RDB is the largest steel manufacturing hub in India and is home to several foundries, metal-alloy plants, steel casting and rolling, sponge iron plants, cement production, and a large chemical (formalin) manufacturing plant. Bhilai Steel plant is the largest integrated steel plant in India. Most of the electricity generation at the power and the steel plants is coal-based. While Durg-Bhilai are largely industrial, Raipur has emerged as the commercial hub.

The city of Raipur has a population of approximately 2.5 million (Census-India, 2012). Nearly half of the state's urban population resides in the RDB region. Naya Raipur 
(New Raipur) is a satellite city located $17 \mathrm{~km}$ away from Raipur and is among the handful of planned cities in India. The city is spread over an area of 8,000 hectares, to house a population of 450,000 by 2030 . Naya Raipur is among the demonstration cities for Sustainable Urban Transport Project (SUTP) and as part of this program, it is focusing on transit-oriented development (TOD), bus rapid transit (BRT) systems, non-motorized transportation (NMT), and intelligent transportation systems (ITS). All three cities rank low in the Swachh Survekshan (a national survey conducted by the Quality Council of India with a focus on cleanliness and sanitation) with Raipur at 129, Durg at 54, and Bhilai at 85, among 434 cities.

Between 1998 and 2016, the satellite and global model data derived concentrations, summarized in Fig. 1, show a 50\% increase in the overall concentrations of $\mathrm{PM}_{2.5}$ (particulate matter with diameter $<2.5 \mu \mathrm{m}$ ) and expected to increase under the business as usual scenario (van Donkelaar et al., 2016). This increase is primarily driven by two key $\mathrm{PM}_{2.5}$ emission sources - a rapid growth in the vehicle numbers and their usage in the city and a constant growth in the industrial sector. Of the 36 states and union territories, Chhattisgarh is ranked $8^{\text {th }}$ for premature mortality due to ambient $\mathrm{PM}_{2.5}$ pollution, with the mortality rates (per 100,000) estimated as 179.4 (70.7-288.2) for COPD (chronic obstructive pulmonary disease), 194.8 (152.9-236.6) for IHD (ischemic heart diseases) and 138.2 (97.7-178.7) (Chowdhury and Dey, 2016). On the other hand, between 2011 and 2015, measurements from the national ambient monitoring programme (NAMP) network show a $28 \%$ reduction in the overall concentrations of $\mathrm{PM}_{10}$ (particulate matter diameter $<10 \mu \mathrm{m})(\mathrm{CPCB}, 2016)$. A large portion of $\mathrm{PM}_{10}$ is dust and a change from unpaved to paved roads in most parts of the city led to this reduction.

An important prerequisite of an air quality management plan is an understanding of where the pollution is coming from - by source and by region. This is usually achieved through receptor modeling (top-down approach involving sampling, chemical analysis, and receptor modeling) or through source modeling (bottom-up approach involving emissions inventory and dispersion). Some receptor modeling studies were conducted in the RDB region, including source profiling. The ambient observations and the study results are summarized in Table 1 . However, there is no source modeling study conducted for the region. While the studies in Table 1 provide some background information on PM pollution sources, a major gap exists in documenting the source emission strengths and accounting for the influence of sources outside the urban airshed. As part of the Air Pollution Knowledge Assessment (APnA) city program for Indian cities, emissions inventory was established for 20 big and medium sized cities with population more than 2 million (India-APnA, 2017; Guttikunda et al., 2019). In this paper, we present (a) a review of the ambient pollution levels (b) the methods and the results of source emissions inventory (c) ambient source contributions from meteorology coupled chemical transport modeling and (d) an evaluation of the source contributions of local and non-local sources to the ambient $\mathrm{PM}_{2.5}$ concentrations in the RDB region.

\section{AIR QUALITY IN RAIPUR}

\section{Ambient Particulate Matter Concentrations}

NAMP network stations in Chhattisgarh are limited to three cities - Raipur, Bhilai and Korba - 8 stations representing approximately 25 million residents. There are no continuous ambient air quality monitoring stations and the regulatory data is derived from manual (gravimetrybased) monitoring methods (CPCB, 2016). Concentrations are typically higher during winter months (Dec-Jan-Feb) and this is in line with broader meteorological conditions in the region, reporting lower mixing heights during winter months (Supplementary). At the state level, average $\mathrm{PM}_{10}$

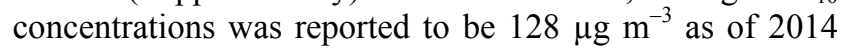
(Fig. 2). In comparison, a study in rural central India reported an average concentration of $339 \pm 143 \mu \mathrm{g} \mathrm{m}^{-3}$ during the winter season. Between 2000 and 2016, studies have analyzed PM concentrations, composition and sources in the region (Table 1). Across research analyses, average reported $\mathrm{PM}_{10}$ concentrations vary between $100-270 \mu \mathrm{g} \mathrm{m}^{-3}$, while the regulatory monitoring stations data varied between 68 and $379 \mu \mathrm{g} \mathrm{m}^{-3}$ for Raipur and Bhilai $\left(175 \pm 110 \mu \mathrm{g} \mathrm{m}^{-3}\right.$ in 2011 and $125 \pm 52 \mu \mathrm{g} \mathrm{m}^{-3}$ in 2015). No data is available for Durg. New sensors were deployed in March 2018, at

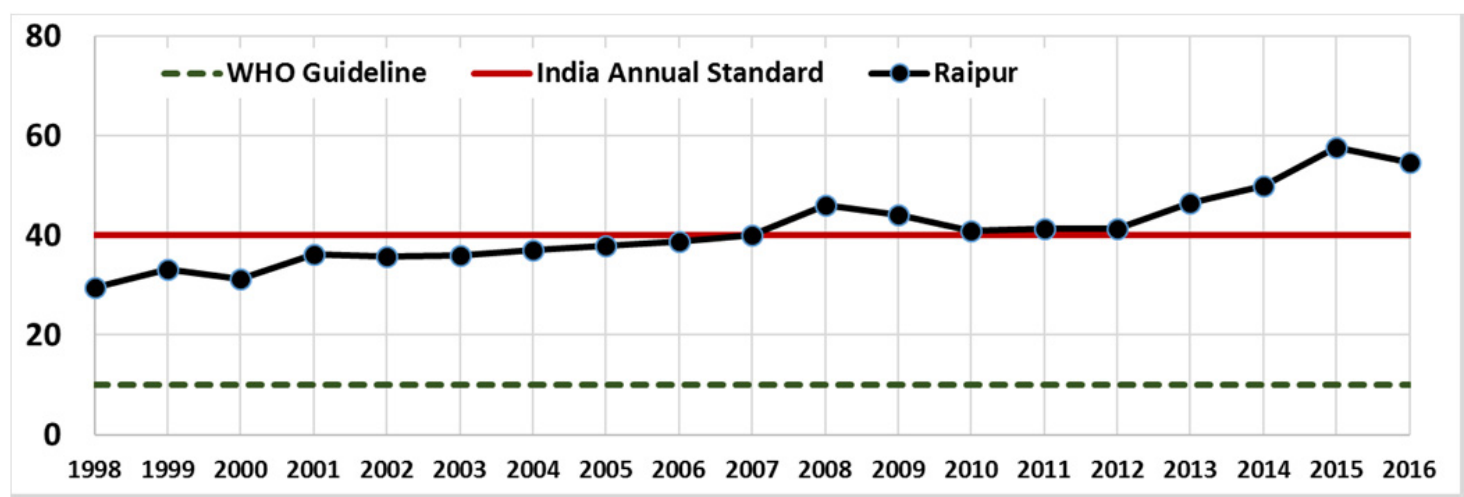

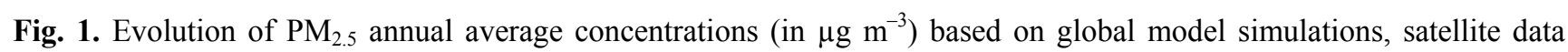
derived estimates, and an assimilation of on-ground measurements for the period of 1998 and 2016 (van Donkelaar et al., 2016) over the Raipur district. 
Table 1. Summary of PM concentrations $\left(\mu \mathrm{g} \mathrm{m}^{-3}\right)$ in the region (data: NAMP and peer-reviewed literature; NAMP stations are manual monitoring stations in all cases).

\begin{tabular}{|c|c|c|c|c|c|}
\hline Pollutant & City & Source & Station type & Concentration & Reference \\
\hline \multirow{10}{*}{$\mathrm{PM}_{10}$} & Raipur & NAMP & Industrial & $258.3 \pm 65.1$ & \\
\hline & & & Residential/Rural/Other (Hirapur) & $214 \pm 57.5$ & \\
\hline & & & Residential/Rural/Other (JSC) & $187 \pm 49.4$ & \\
\hline & & Research Study & & $270.5 \pm 105.5$ & Deshmukh et al. (2013) \\
\hline & & & & $246 \pm 68$ & Giri et al. (2013) \\
\hline & & & & $106-314$ & Dubey and Pervez (2008) \\
\hline & Bhilai & NAMP & Industrial & $172 \pm 43.0$ & \\
\hline & & & Residential/Rural/Other (RO) & $79.5 \pm 9.13$ & \\
\hline & & & Residential/Rural/Other (Hostel) & $98.8 \pm 17.6$ & \\
\hline & Durg & Research Study & & $253.5 \pm 99.4$ & Deshmukh et al. (2012) \\
\hline $\mathrm{PM}_{2.5-10}$ & Raipur & Research Study & & $238.1 \pm 89.9$ & Verma et al. (2010) \\
\hline \multirow[t]{4}{*}{$\mathrm{PM}_{2.5}$} & Raipur & & & $150.9 \pm 78.6$ & Deshmukh et al. (2013) \\
\hline & & & & $115 \pm 36$ & Giri et al. (2013) \\
\hline & & & & $167.0 \pm 75.3$ & Verma et al. (2010) \\
\hline & Durg & Research Study & & 135 & Deshmukh et al. (2011) \\
\hline \multirow[t]{2}{*}{$\mathrm{PM}_{1}$} & Raipur & Research Study & & $72.5 \pm 39.0$ & Deshmukh et al. (2012) \\
\hline & Durg & Research Study & & 64.7 & Deshmukh et al. (2011) \\
\hline
\end{tabular}

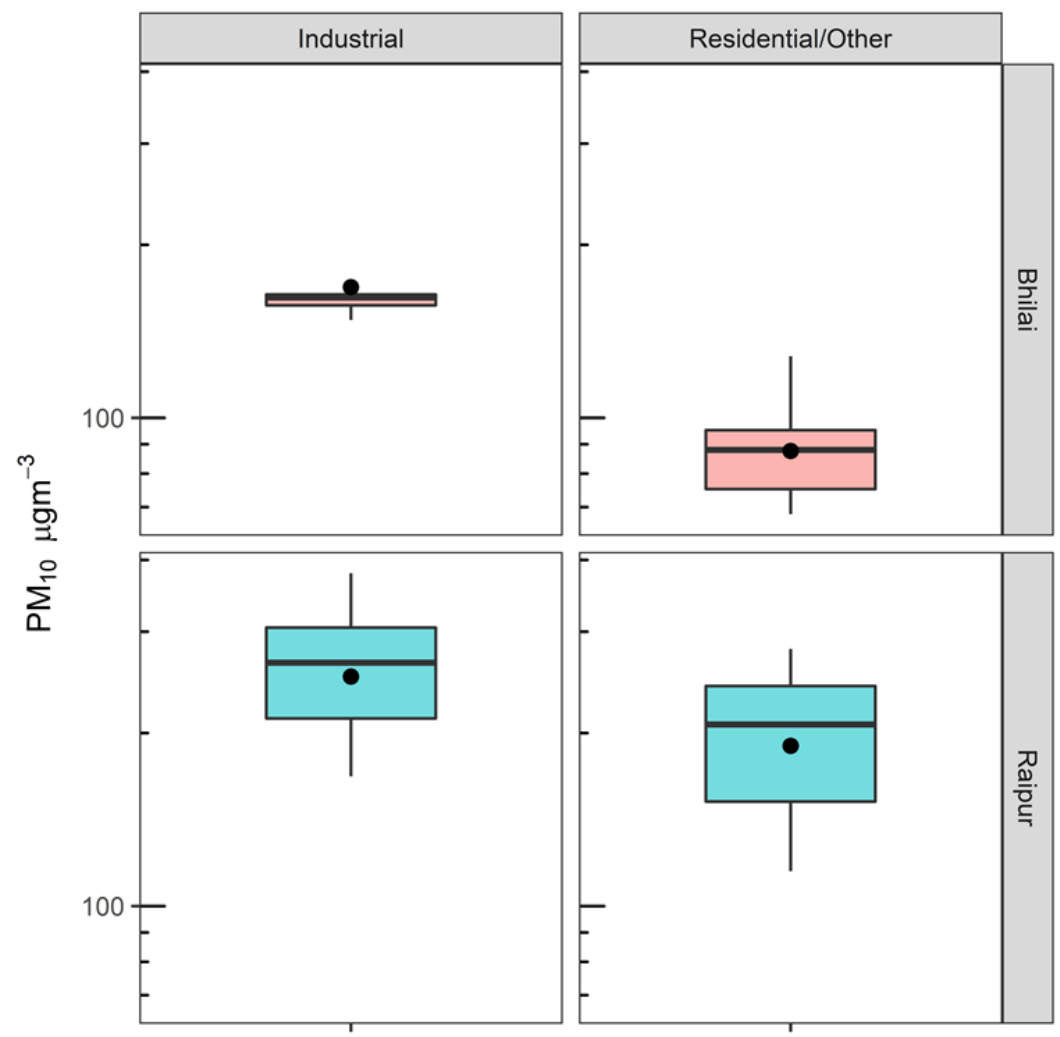

Fig. 2. Summary of reported annual average $\mathrm{PM}_{10}$ concentrations (gravimetric measurements) from the National Ambient Monitoring Program (NAMP) in India for Raipur and Bhilai between 2004 and 2016.

three locations in the region, under the auspices of citizen science, to further support the regulatory network (Urban Sciences, 2018; Zheng et al., 2018). These measurements ranged $102 \pm 53 \mu \mathrm{g} \mathrm{m}^{-3}$ for $\mathrm{PM}_{10}$ and $87 \pm 46 \mu \mathrm{g} \mathrm{m}^{-3}$ for $\mathrm{PM}_{2.5}$ for the month of March 2018. Based on satellitederived measurements and global model simulations, average $\mathrm{PM}_{2.5}$ concentration is $38 \pm 22 \mu \mathrm{g} \mathrm{m}^{-3}$ for the $\mathrm{RDB}$ region
(Chowdhury and Dey, 2016). On average, concentrations are higher in Raipur and unsurprisingly, the concentrations at industrial sites in both cities have higher concentrations.

\section{Air Pollution Sources}

Chhattisgarh hosts large coal-fired thermal power plants and other industrial facilities (Guttikunda and Jawahar, 
2014; Guttikunda and Jawahar, 2018). In early 2000s, one study in the Korba region, demonstrated a significant increase in $\mathrm{PM}_{10}$ concentrations, downwind of a coal-fired power plant, with average concentrations 4-6 times the concentrations in the upwind region (Sharma et al., 2005). In another study, the sponge iron industries were found to make significant contribution (Rao et al., 2008). Subsequent studies have reported air quality impacts from industrial emissions (Dubey and Pervez, 2008), but there are no concerted modelling studies on the impact of the industrial activity on ambient air quality in the region.

Receptor modelling studies have identified several sources for PM including industrial emissions, traffic, brick kilns, dust, agricultural burning and waste combustion (Deshmukh et al., 2011). Field data also suggests similar sources for $\mathrm{PM}_{10}$ and $\mathrm{PM}_{2.5}$, given the high correlation between the two pollutants. In Durg, Deshmukh et al. (2012) reported coal and biomass combustion, vehicular emissions and secondary aerosol production as major sources of $\mathrm{PM}_{10}$, while a study in rural central India (Rajim, Chhattisgarh) reported biomass burning, dust re-suspension and biogenic activity as major sources for $\mathrm{PM}_{10}$ (Nirmalkar et al., 2015). Crop burning is a common source of PM during specific times of the year, when farmers burn agricultural residues typically twice a year in March/April and October/November (Deshmukh et al., 2016). Open waste burning is an important and uncertain source for PM pollution in the Indian subcontinent (Wiedinmyer et al. 2014) and a noted source of pollution in RDB (Matawle et al., 2014). Watersoluble ions have been reported to constitute $\sim 12 \%$ of the total $\mathrm{PM}_{2.5}$ mass with sulfate, nitrate and ammonium being the most dominant ions (Deshmukh et al., 2011), associated with significant coal and oil combustion in the region for steel and power generation (Guttikunda and Jawahar, 2014). Receptor models utilized in these studies are chemical mass balance (CMB) and positive matrix factorization (PMF).

Based on chemical speciation of dust in Raipur, Patel et al. (2015) reported high concentrations of Fe, Mn and at locations affected by industrial emissions, and high concentrations of $\mathrm{Cu}, \mathrm{Pb}$ and $\mathrm{Zn}$ at traffic-influenced sites. Heavy metal emissions have been associated with a variety of PM sources including industrial activities, traffic emissions and waste burning. During winter, concentration of specific markers for wood/biomass combustion (e.g., $\mathrm{K}^{+}, \mathrm{Cl}^{-}$) have also been reported to have highest concentrations (Deshmukh et al., 2010, 2013). Within the inorganic aerosol fraction, sulphate $\left(\mathrm{SO}_{4}{ }^{2-}\right)$, nitrate $\left(\mathrm{NO}_{3}{ }^{-}\right)$and chloride $\left(\mathrm{Cl}^{-}\right)$are reported to be most abundant (Deshmukh et al., 2010, 2013).

In India, limited source profiles are available for local sources and most receptor modelling studies use SPECIATE profiles which were developed for the USA (Pant and Harrison, 2012). A library of chemical profiles was established for various $\mathrm{PM}_{10}$ and $\mathrm{PM}_{2.5}$ sources in the RDB region (Matawle et al., 2014, 2015; Bano et al., 2018; Pervez et al., 2018). Matwale et al. (2014) presents 11 chemical source profiles for $\mathrm{PM}_{2.5}$ - one related to solid waste burning, three related to household fuel combustion, and seven related to industrial fuel combustion while Matawle et al. (2015) includes profiles for vehicular emissions and dust sources.

\section{SOURCE EMISSION MODELING}

Total emissions inventory is established for all the key pollutants necessary to support urban-scale chemical transport dispersion modeling - $\mathrm{PM}_{2.5}, \mathrm{PM}_{10}$, black carbon (BC), organic carbon $(\mathrm{OC}), \mathrm{SO}_{2}$, nitrogen oxides $\left(\mathrm{NO}_{\mathrm{x}}\right)$, carbon monoxide $(\mathrm{CO})$, non-methane volatile organic compounds (NMVOCs), and carbon dioxide $\left(\mathrm{CO}_{2}\right)$.

\section{Urban Airshed}

The urban airshed for the RDB region is selected to cover the main district area, the neighboring satellite cities, industrial zones, and locations with sources that could influence the air quality in the city. The geographical location of the cities is presented in Fig. 3(a), along with the main roads, highways, points of interest, brick kiln clusters, and the water bodies. The RDB region is divided into $60 \times 30$ grids, with a spatial resolution of $0.01^{\circ}$ grids (approximately $1-\mathrm{km}$ ) - extending between $81.2^{\circ} \mathrm{E}$ and $81.8^{\circ} \mathrm{E}$ in longitude and $21.05^{\circ} \mathrm{N}$ and $21.35^{\circ} \mathrm{N}$ in latitude. Total population covered in this region is approximately 4 million. Of the 1,800 grids, $20 \%$ are designated as urban, hosting $90 \%$ of the population. Fig. 3(b) presents the builtup area which increased 84\% between 1990 and 2014 (Pesaresi et al., 2016).

\section{Methodology and Inputs}

The methods utilized for collating and organizing the necessary and available information were previously utilized for similar urban scale exercises for 10 Indian cities - Pune, Chennai, Ahmedabad, Indore, Surat, Rajkot, Hyderabad, Chennai, Vishakhapatnam, and Delhi (Guttikunda and Jawahar, 2012; Guttikunda and Calori, 2013; Guttikunda and Kopakka, 2014; Guttikunda and Mohan, 2014; Guttikunda et al., 2014). These studies and Guttikunda et al. (2019) present the overall methods, emission factor libraries, and general assumptions to establish an emissions inventory for the RDB region. Applicable emission factors for transport, industrial, and domestic sectors were collated from multiple sources (CPCB, 2010; Pandey et al., 2014; IIASA, 2015). The emissions inventory is interfaced with geospatial platforms to support urban and regional chemical transport modeling.

For the transport sector, vehicle exhaust emissions were calculated using (a) total travel activity (b) modal shares in vehicle-km traveled per day (c) modal energy intensity representing energy use per kilometer and (d) an emission factor defined as the mass of pollutant emitted per vehicle$\mathrm{km}$ travelled (Schipper et al., 2000). The city level exhaust emissions are broken down by vehicle age and fuel type, as discussed in Guttikunda and Mohan (2014), to allow for variation in the emission factors with usage. We estimated re-suspension of dust on roads using the USEPA AP-42 methodology (USEPA, 2006; Kupiainen, 2007). The total in-use fleet is 1.4 million in 2015. This consists of $78 \%$ motorcycles and scooters, $8.5 \%$ cars, jeeps, taxis, 3-wheeler passenger vehicles, and utility vehicles, $2 \%$ buses, and $11.5 \%$ 

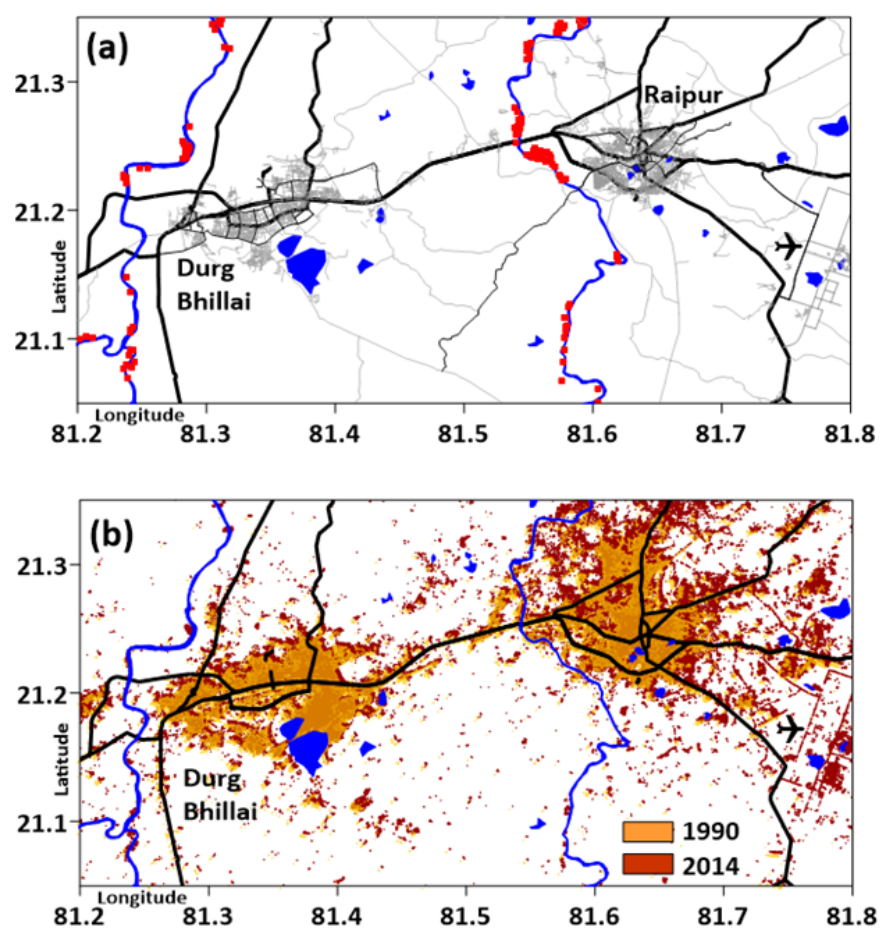

Fig. 3. (a) Urban airshed selected for the Raipur-Durg-Bhilai region including main roads (thick lines), arterial roads (light lines), water bodies (blue lines), airport location, and brick kilns (red dots) and (b) Built-up area for the Raipur-DurgBhilai region in 1990 and 2014.

covering the rest - heavy and light duty vehicles (HDVs and LDVs) and others (MoRTH, 2016). The overall emissions in this sector were further segregated spatially and temporally using multiple layers of proxy information.

- For spatial and temporal allocation of emissions by grid, we employed the speed data from google maps, which is accessible via an API, for a charge. Over the $\mathrm{RDB}$ region, transit speeds are extracted at 1 sq.km resolution, which is used as a proxy to dynamically allocate vehicle exhaust emissions and estimate road dust resuspension. For example, during peak times, if a grid shows speeds less than $5 \mathrm{~km} \mathrm{~h}^{-1}$, then the emission profile is adjusted to increase the exhaust emissions due to idling and the road dust resuspension is zeroed to reflect that the vehicles are moving under the threshold speed to resuspend dust. Similarly, the emissions and the dust resuspension were adjusted depending on the grid average speed.

- The spatial allocation of the emissions is further refined using the hotspot information available as geospatial layers, including the locations of hotels, hospitals, malls, markets, funeral homes, religious worship centers, industrial areas, apartment complexes, commercial centers, bus and rail stops, refueling stations, and traffic signals. These layers were extracted from open sources, such as Open Street Maps, for the designated urban airshed, and used to create an origin-destination matrix.

- The modeled meteorological data at 1 sq.km grid resolution is further linked to the temporal allocation of the emissions. For example, (a) grids with precipitation over $1 \mathrm{~mm}$ per hour, are adjusted for lesser vehicle movement (b) grids with precipitation are adjusted for no road dust resuspension and at the construction sites; and maintained at lower levels, depending on the modeled surface moisture content.

The transport sector emissions also include aviation, for which landing and takeoff (LTO) statistics are obtained from the directorate general of civil aviation (DGCA). Assuming average occupancy per flight of approximately 180 , we estimated the idling emissions of cars dropping off and picking up passengers and emissions from general airport operations. The new Raipur airport operates between 30-40 LTOs per day, with most of them operating during the day, serving domestic destinations, and is expected to at least triple its operations by 2020 , including some international flights.

The domestic sector emissions inventory for cooking, heating, lighting, and open waste burning, is based on fuel consumption estimates, waste collection estimates, gridded population, and landuse statistics. Using Census-India (2012) database at the district level and gridded population at 30-second spatial resolution from GRUMP (2015), total household energy consumed in the form of solid (coal and wood), liquid (kerosene), and gaseous (LPG) fuels was estimated. Across central India, indoor fuel use distribution is $25 \%$ LPG, $30 \%$ kerosene and $45 \%$ conventional solid fuels. In the urban RDB, approximately $60 \%$ of the households use LPG as their primary fuel, compared to $15 \%$ in the rural areas. In the peri-urban areas, construction sites, restaurants, and areas outside the municipal boundary, use of coal, biomass, and agricultural waste is common. Kerosene is also 
utilized for lighting in the rural areas - with approximately $19 \%$ of households' dependent on this method, compared to less than $3 \%$ in urban areas. The modeled surface temperature data at $1 \mathrm{sq} . \mathrm{km}$ resolution is linked to temporal allocation of domestic space heating emissions, by looking at the running surface temperature profile as the trigger, with a threshold surface temperature set at $14.5^{\circ} \mathrm{C}$.

Matwale et al. (2014) established the chemical profile for the open waste burning, a key source of air pollution in the RDB region with limited efforts to manage solid waste. The National Green Tribunal of India and the municipal authorities have banned open waste burning, but it is often noticed during the morning hours when the waste is collected or late night at the collection hubs and kerbside. In general, the urban areas have higher waste collection efficiency. The region generates 2,000 to 3,000 tons of solid waste per day, of which we estimate approximately $25 \%$ is burnt in the residential areas and approximately $5 \%$ at the landfills. The modeled precipitation data at the model grid resolution, with a threshold of $1 \mathrm{~mm}$ per hour, is also used to zero the open waste burning emissions, during the dispersion model simulations.

The RDB region is an industrial hub, housing 21 registered large iron and steel plants, 3 cement manufacturing units, and coal-based power plant in Bhilai. The Annual Survey of Industries (ASI, 2015) records show an additional 800 to 1,000 small scale industries in RDB's airshed, consuming approximately 13.5 million $\mathrm{kg}$ of natural gas, 22 million liters of liquid fuel, and 70,000 tons of coal per year. Besides the traditional manufacturing industries, there are 120 brick kilns to support the growing demand in the construction sector (marked in Fig. 3(a) using the google earth images). This fuel used for baking the sun-dried bricks varies from agricultural waste during the harvest seasons to biofuels like cow dung and wood to fossil fuels like coal and heavy fuel oil. The emerging technologies and emission factors for kilns in India are documented in Mathiel et al. (2012). The inventory also includes fugitive dust estimates for construction sites based on empirical functions (USEPA, 2006).

The state of Chhattisgarh has a total power generation capacity of $17 \mathrm{GW}$ from 66 coal-fired units (Guttikunda and Jawahar, 2014). The Bhilai coal-fired power plant, commissioned in 2008, has five captive power generation units of $1 \times 14 \mathrm{MW}$ and $2 \times 30 \mathrm{MW}$ and $2 \times 250 \mathrm{MW}$ units. While most of the electricity needs are met by the grid electricity, a large proportion of mobile phone towers, hotels, hospitals, malls, markets, large institutions, apartment complexes, and cinemas, supplement their electricity needs with in-situ diesel generator sets. Based on the data available from the load dispatch centers, the total diesel consumption at the in-situ generator sets is estimated at 130 million liters per year.

\section{RESULTS}

For 2015, the emissions inventory results are summarized in Table 2, with estimates of 41,500 tons of $\mathrm{PM}_{2.5}, 59,650$ tons of $\mathrm{PM}_{10}, 7,600$ tons of $\mathrm{SO}_{2}, 67,000$ tons

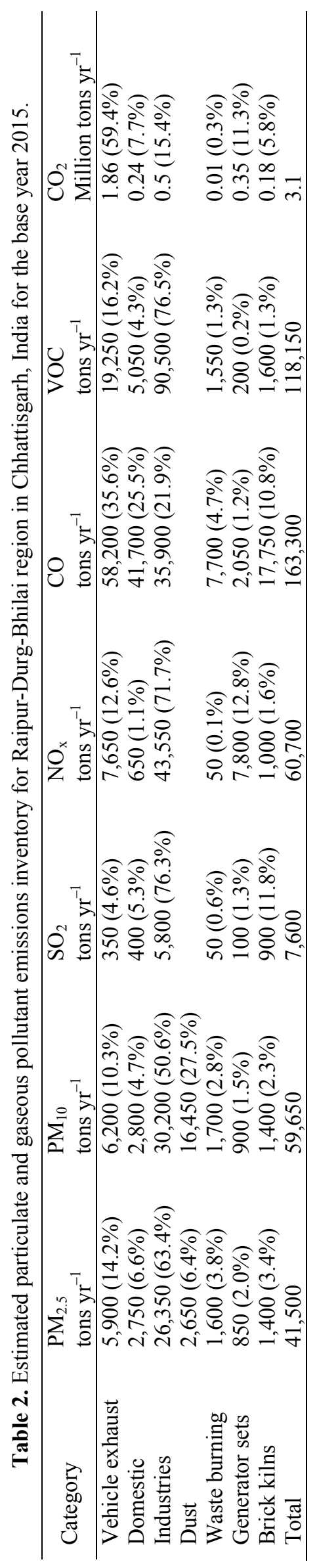


of $\mathrm{NO}_{\mathrm{x}}, 163,300$ tons of $\mathrm{CO}, 118,150$ tons of NMVOCs, and 3.1 million tons of $\mathrm{CO}_{2}$. Under the APnA city program, for 20 Indian cities, average total $\mathrm{PM}_{2.5}$ emissions are 22,500 tons/year/city with a maximum of 94,000 tons/year from the city of Chennai (metropolitan city with $10+$ million population, large vehicle fleet, and large industrial area with a commercial port) and a minimum of 5,000 tons year ${ }^{-1}$ from the city Dehradun (hilly, tourist destination) (India-APnA, 2017). This inventory total does not include the seasonal open fires, dust storms, or lightning, whose emissions are linked to the on-line calculations at the dispersion modeling stage, designated as regional contributions. According to Jain et al. (2014), approximately $9 \mathrm{Mt}$ year $^{-1}$ of crop residue is generated while approximately $0.73 \mathrm{Mt} \mathrm{year}^{-1}$ of the residue is burnt in Chhattisgarh, resulting in $2.86 \mathrm{Gg}_{\text {year }}{ }^{-1}$ of $\mathrm{PM}_{2.5}$, $0.51 \mathrm{Gg} \mathrm{year}^{-1}$ of black carbon (BC) and $9.53 \mathrm{Gg} \mathrm{year}^{-1}$ of total PM.

For $\mathrm{PM}_{10}$ and $\mathrm{PM}_{2.5}$, industries, dust (due to constant movement of the vehicles on the roads), and vehicle exhaust account for $88 \%$ and $84 \%$ of the total inventory, respectively, with the remainder from residential fuel combustion, garbage burning, construction activities, and generator usage at commercial and residential locations. This is due to a large industrial estate, involving coal combustion and movement of raw and finished products via HDVs and LDVs. Constant movement of trucks on dusty roads lead to further resuspension of dust in the region. This is unlike the other capital cities in India, where the vehicle exhaust is expected to be the primary emission source (Guttikunda and Jawahar, 2012). Similarly, for $\mathrm{SO}_{2}, \mathrm{NO}_{\mathrm{x}}$ and $\mathrm{VOC}$, industries remain the primary source of emissions (above 70\%). For CO, share of emissions are spread equally between vehicle exhaust, domestic cooking and heating, and industries. The total emissions estimation has an uncertainty of $\pm 20-30 \%$. The details for various sectors is in the Supplementary.

The total emissions were also projected to 2030. The growth rates, summarized in the Supplementary, are considered an underestimate, based on the proposed urban development programs, industrial development trends, and regional landuse patterns. The vehicle growth rate is assumed from the national road transport emissions study (Guttikunda and Mohan, 2014; Prakash and Habib, 2018) and the sales projection numbers from Society of Indian Automobile Manufacturers (SIAM, New Delhi, India). The industrial growth is projected according to the gross domestic product of the state. The domestic sector, construction activities, brick demand, diesel usage in the generator sets, and open waste burning are linked to the population growth rates according to the 2011 census (Census-India, 2012). We used these estimates to evaluate the likely trend in the total emissions and their likely impact on ambient $\mathrm{PM}_{2.5}$ pollution in 2030. The total $\mathrm{PM}_{2.5}$ emissions between 2015 and 2030 (Fig. 4) are expected to increase 24\%, with the overall shares of the main sectors remaining constant. For convenience, only gridded $\mathrm{PM}_{2.5}$ emissions figures are presented in this paper. More details are available at IndiaAPnA (2017).

The emissions inventory for the designated airshed is spatially segregated at $0.01^{\circ}$ resolution suitable for chemical transport modeling. The gridded total $\mathrm{PM}_{2.5}$ emissions for 2015 and 2030 are presented in Fig. 5. We used spatial proxies to allocate the emissions from each sector to the grid, like the methodology utilized in for multiple cities in India Guttikunda and Jawahar, 2012). Various layers of information include grids designated as urban and rural, based on the built-up area and population density (Fig. 3); grid based population density; gridded road density for highways, arterial roads, and feeder roads; and location of manufacturing and commercial activities like industries, brick kilns, hotels, hospitals, apartment complexes, institutions, funeral homes, telecom towers, and markets. These methods and databases are detailed in Guttikunda et al. (2019) In Fig. 5, for $\mathrm{PM}_{2.5}$, the highest density of emissions is in the city due to vehicle exhaust and along the industrial estates including brick kiln clusters in the airshed.

\section{SOURCE DISPERSION MODELING}

\section{Dispersion Model}

Urban atmospheric dispersion modeling was conducted utilizing the Comprehensive Air Quality Model with Extensions (CAMx - http://www.camx.com) - an opensource Eulerian photochemical dispersion model with (a) modular structure to process ground and point sources (b) detailed atmospheric advection and scavenging schematics

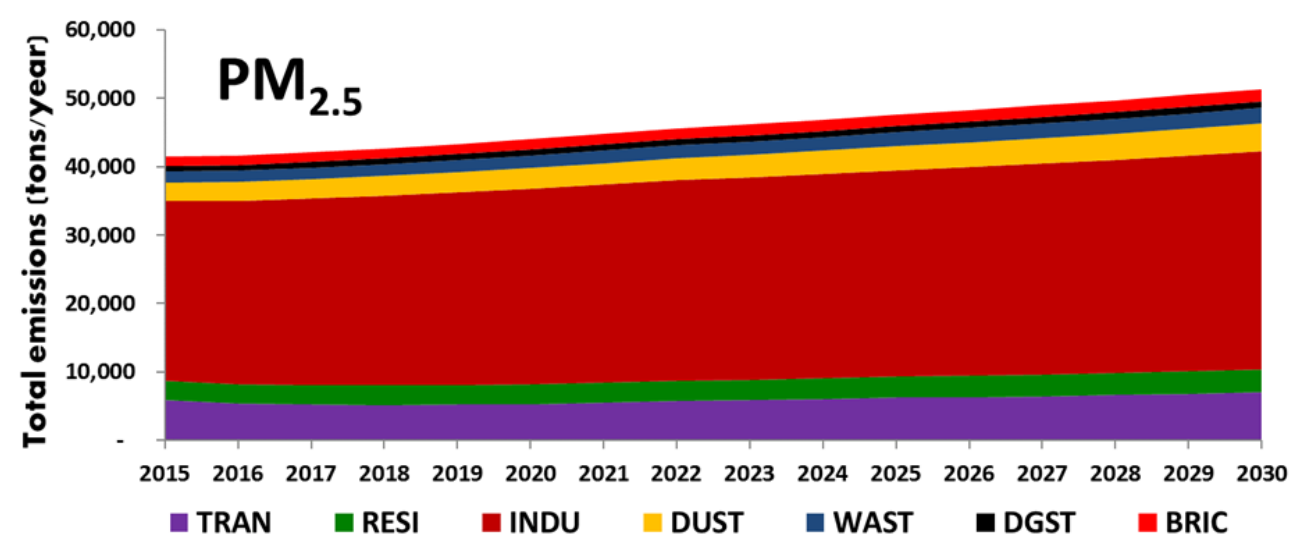

Fig. 4. Total $\mathrm{PM}_{2.5}$ emissions projection for Raipur-Durg-Bhilai region between 2015 and 2030. 

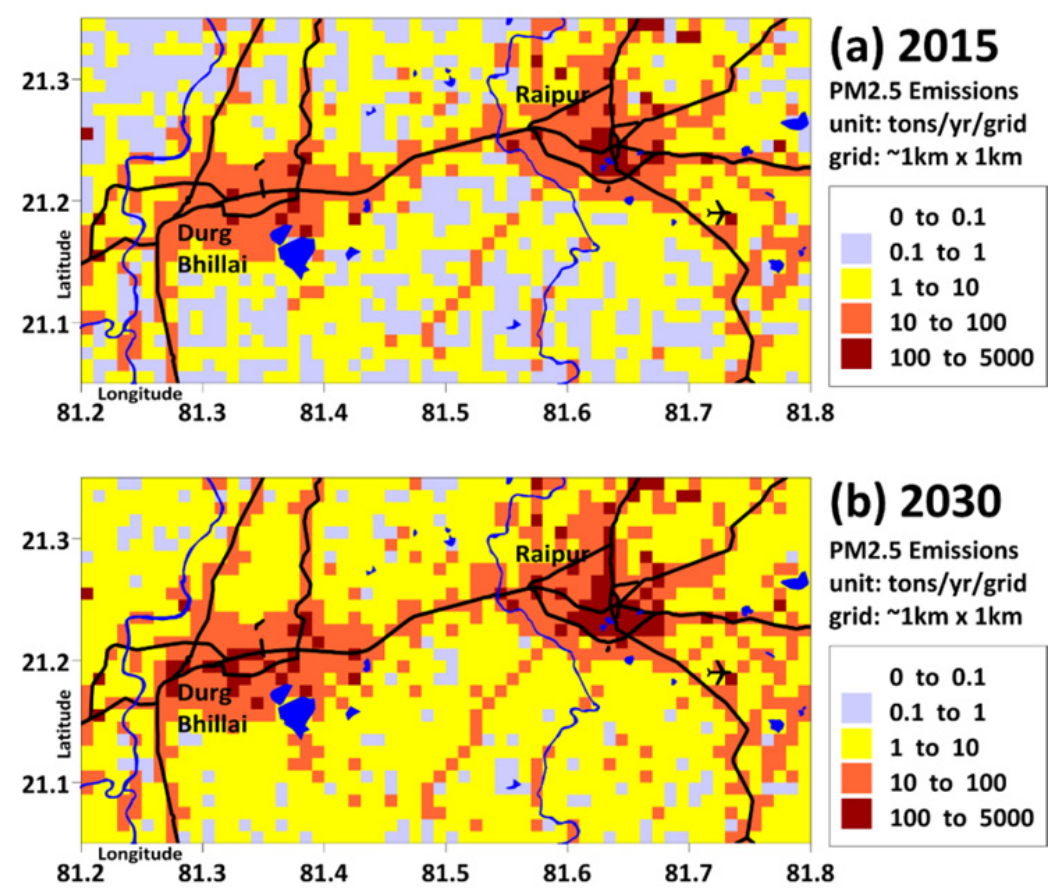

Fig. 5. Gridded total $\mathrm{PM}_{2.5}$ emissions estimated for the Raipur-Durg-Bhilai region for year (a) 2015 and (b) 2030 .

(dry and wet deposition) to support regional and urban topography (c) chemical solvers for multiple chemical mechanisms (we utilized SAPRC99) (d) online emission calculations where necessary, including plume rise calculations linked to 3D meteorological fields (e) modules to support gas $\left(\mathrm{SO}_{2}, \mathrm{NO}_{\mathrm{x}}\right.$, and VOC) to aerosol (sulfates, nitrates, and secondary organic aerosols) conversions.

The meteorological data (3D wind, temperature, pressure, relative humidity, and precipitation fields) is derived from the National Center for Environmental Prediction (NCEP, 2015) global reanalysis database and processed through WRF meteorological model at 1-hour temporal resolution. A summary of the key meteorological parameters for 2015 is presented in the Supplementary. Annual average temperature for the region is $27^{\circ} \mathrm{C}$, with highs in the summer and lows in the winter. The same trend is also apparent in the mixing layer heights, with highs of approximately $2 \mathrm{~km}$, observed during April and May, before the onset of monsoons. The predominant wind directions are North and West, with the wind speeds under $4 \mathrm{~m} \mathrm{~s}^{-1}$ for most part of the year. Climatic conditions are often very stable during the winter months resulting in poor dispersion and higher pollution levels (Pandey et al., 2008; Guttikunda and Gurjar, 2012).

To account for long-range transport contributions and for activities outside the designated urban airshed, two model runs are conducted. A national scale simulation was conducted over the Indian Subcontinent at $0.25^{\circ}$ grid resolution (details on national emissions inventory and modeling framework are available online @ http://www.indiaairquality.info), which was utilized to produce boundary conditions for the RDB region at 1-hour temporal resolution. The boundary conditions for the India Subcontinent were obtained from MOZART global model, for which a pre-processor module is available with the CAMx modeling system.

\section{Modeled Particulate Concentrations}

The modeled annual average concentrations for $\mathrm{PM}_{2.5}$ and $\mathrm{PM}_{10}$ is presented in Figs 6(a)-6(b), which includes both primary $\mathrm{PM}$ and secondary sulfates and nitrates via chemical transformation of $\mathrm{SO}_{2}$ and $\mathrm{NO}_{\mathrm{x}}$ emissions. All the secondary aerosols are considered as part of $\mathrm{PM}_{2.5}$ mass. Most of the urban airshed exceeds the national annual standards of $40 \mu \mathrm{g} \mathrm{m}^{-3}$ for $\mathrm{PM}_{2.5}$ and $60 \mu \mathrm{g} \mathrm{m}^{-3}$ for $\mathrm{PM}_{10}$. Monthly variation in PM concentrations for all the grids covering the urban built-up area is presented in Figs. 6(c)6(d). The seasonality, with the lowest concentrations in the summer months is primarily due to significant rains and the highest concentrations in the winter months is primarily due to the dry season. The modeled annual average for $\mathrm{PM}_{2.5}$ is $82 \pm 22 \mu \mathrm{g} \mathrm{m}^{-3}$ and $\mathrm{PM}_{10}$ is $118 \pm 34 \mu \mathrm{g} \mathrm{m}^{-3}$.

The annual average $\mathrm{PM}_{10}$ concentration measured at NAMP's commercial, industrial, and residential monitoring stations in Raipur and Bhilai is $125 \pm 52 \mu \mathrm{g} \mathrm{m}^{-3}$ in 2015. None of these stations currently measure $\mathrm{PM}_{2.5}$. For the month of March 2018, measurements ranged $102 \pm 53 \mu \mathrm{g} \mathrm{m}^{-3}$ for $\mathrm{PM}_{10}$ and $87 \pm 46 \mu \mathrm{g} \mathrm{m}^{-3}$ for $\mathrm{PM}_{2.5}$ from the open platform sensor network. While the monitoring data is very limited to make any qualitative comparisons, the ranges in the measured data, exhibit good confidence in the modeled $\mathrm{PM}_{2.5}$ and $\mathrm{PM}_{10}$ emissions and concentrations.

\section{Source Contributions}

The WRF-CAMx system was also utilized to evaluate sectoral contributions to ambient $\mathrm{PM}_{2.5}$ pollution in the RDB region. We summarized the percentage contribution of the major sectors - vehicle exhaust, resuspended dust 


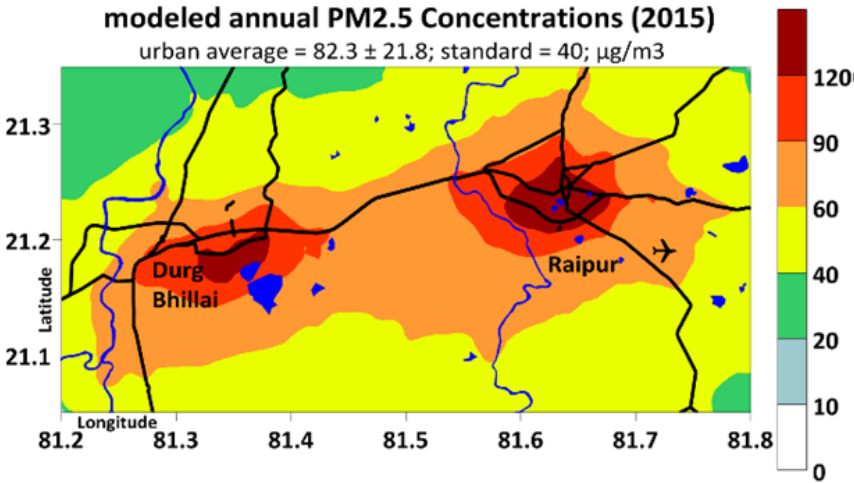

(a)

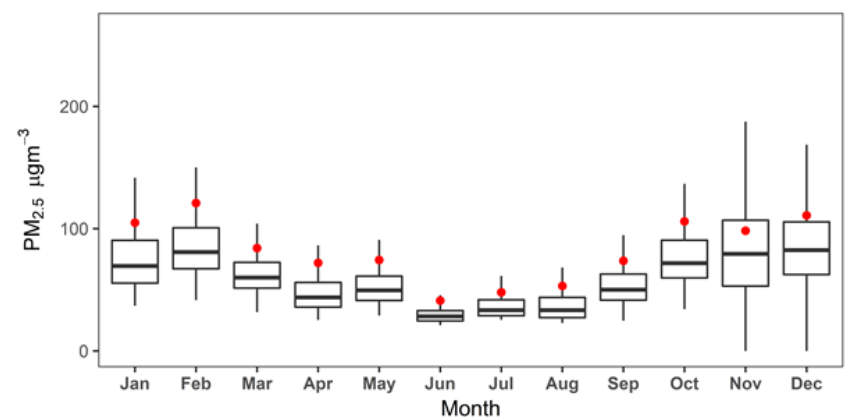

(c)

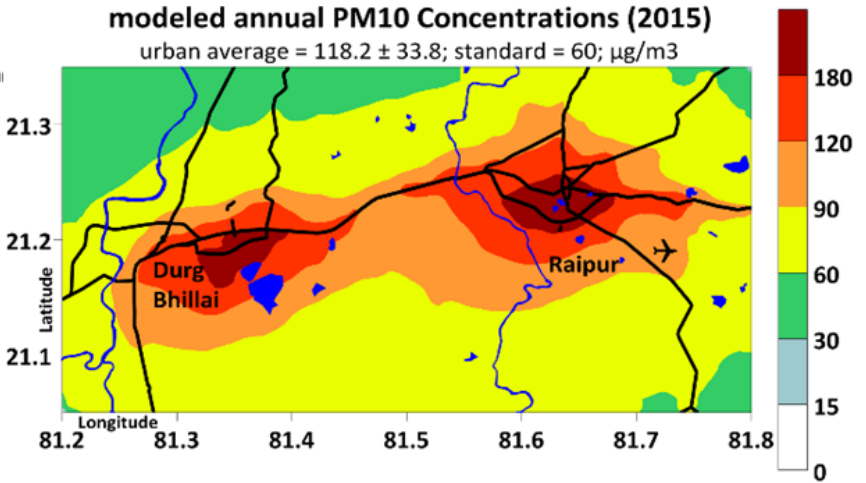

(b)

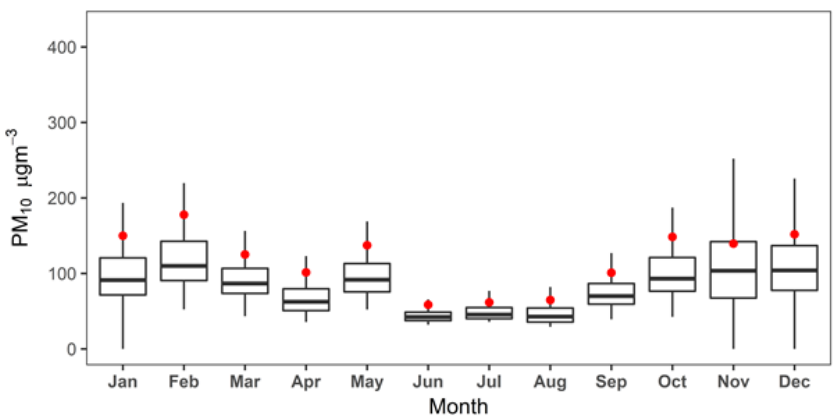

(d)

Fig. 6. (a-b) Modeled $\mathrm{PM}_{2.5}$ and $\mathrm{PM}_{10}$ concentrations for the Raipur-Durg-Bhilai region for year 2015 and (c-d) Variation in modeled monthly $\mathrm{PM}_{2.5}$ and $\mathrm{PM}_{10}$ concentrations for year 2015. The variation of monthly average concentrations is for all 1,800 grid cells - with the box plot representing the $25^{\text {th }}, 50^{\text {th }}$ (mean), and $75^{\text {th }}$ percentile and the error bars representing the $5^{\text {th }}$ and $95^{\text {th }}$ percentile concentrations. The dot represents the urban average concentration.

(including dust due to vehicle movement on the roads and due to the construction activities), industries (including brick kilns), and residential sector (including domestic cooking and open waste burning) in Table 3 and Fig. 7. The boundary conditions from the Indian Subcontinent simulation available at a temporal resolution of 1-hour (with details at http://www.indiaairquality.info) allowed for estimating the non-urban contributions to RDB's ambient $\mathrm{PM}_{2.5}$ concentrations.

The modeled source contributions highlight the heavy industries (mostly steel) (23\%), followed by transport (including on-road dust) (29\%), domestic cooking and heating $(12 \%)$, and open waste burning $(6 \%)$ as the key air pollution sources. The city has an estimated $26 \%$ of the ambient annual $\mathrm{PM}_{2.5}$ pollution originating outside the urban airshed - this contribution is mostly coming from the coal-fired power plants, large (metal and non-metal processing) industries, and brick kilns located outside the urban airshed and seasonal open biomass fires. During the summer and monsoonal months (June-September) this goes up to $40 \%$. The share of diesel generator sets is comparatively low, due to captive power plants at the iron and steel industries, supporting the demand during the off-peak hours. For reference, in the cities of Pune, Ahmedabad, Indore, Chennai, Surat, and Rajkot, the in-situ power generation from the diesel generator sets accounted for up to $10 \%$ in the urban areas (Guttikunda and Jawahar, 2012) and up to $17 \%$ in the populated areas of the Greater Delhi region
(Guttikunda and Calori, 2013). The monthly variation is strong for the domestic and the dust sectors. As the temperatures drops between October-December, a small increment is evident in the domestic heating sector (11$13 \%$ versus $9 \%$ in July). Similarly, a drop is evident in the dust contributions during the monsoonal months.

None of the studies in Table 1 include information on percentage contributions of different sources to total $\mathrm{PM}_{2.5}$ concentrations. Using data on water-soluble ions in $\mathrm{PM}_{2.5}$ and $\mathrm{PM}_{1}$ from Raipur and Durg, Deshmukh et al. (2010) and Deshmukh et al. (2011) reported contributions from two major sources - soil/crustal dust and combustion emissions including biomass and fossil fuel burning. In a more recent study in slum communities, Matawle et al. (2018) apportioned $40 \%$ of the total indoor PM to solid fuel combustion, $30 \%$ of traffic emissions, $26 \%$ coal-ash based construction materials and $4.3 \%$ to iron-processing industries in the area, using Positive Matrix Factorization (PMF). These results, however, are difficult to interpret with respect to ambient air since the results are based on indoor measurements.

\section{DISCUSSION}

A key ingredient for urban air quality management is a robust ground monitoring network. As of April 2018, there are 2 manual monitoring stations in Raipur, 1 manual monitoring station in Durg-Bhilai, and no continuous 


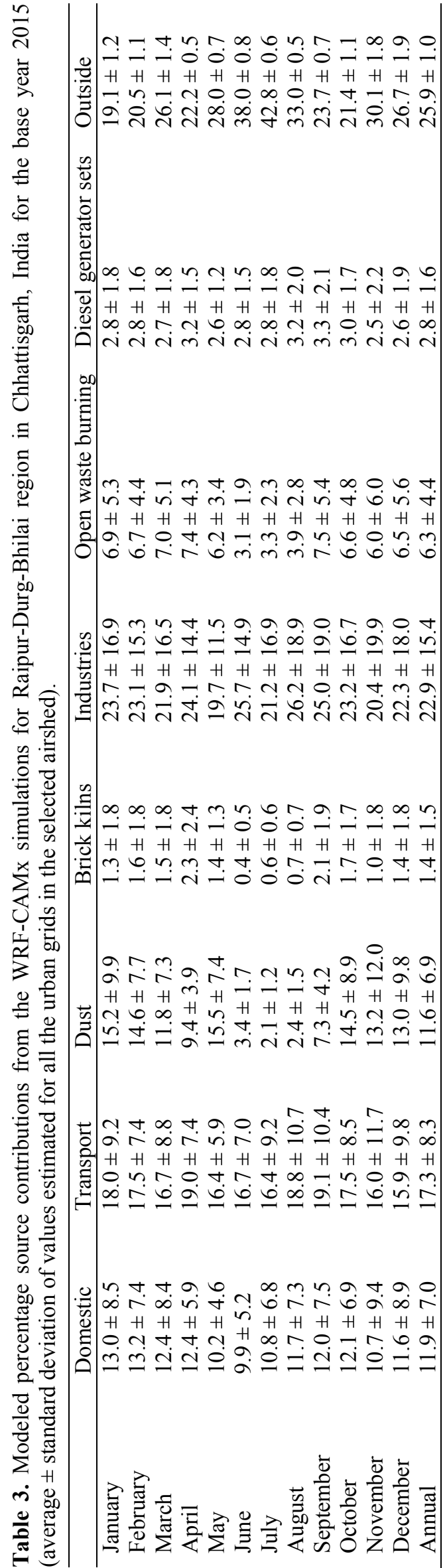

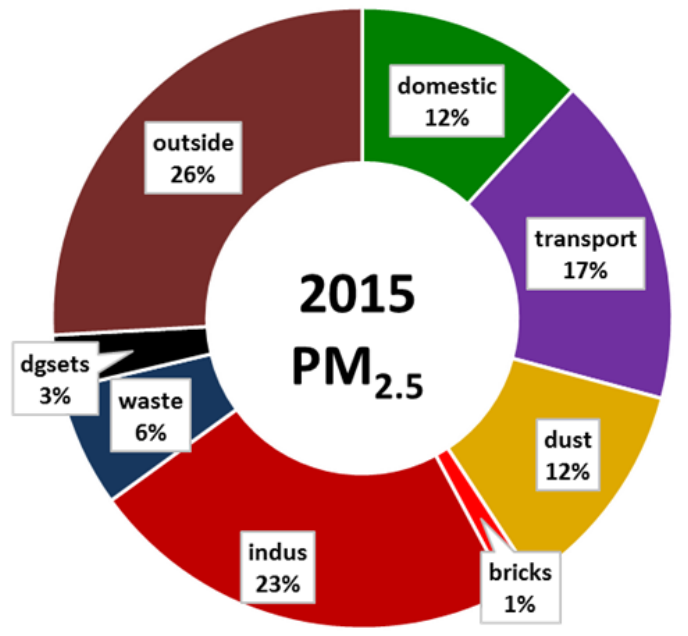

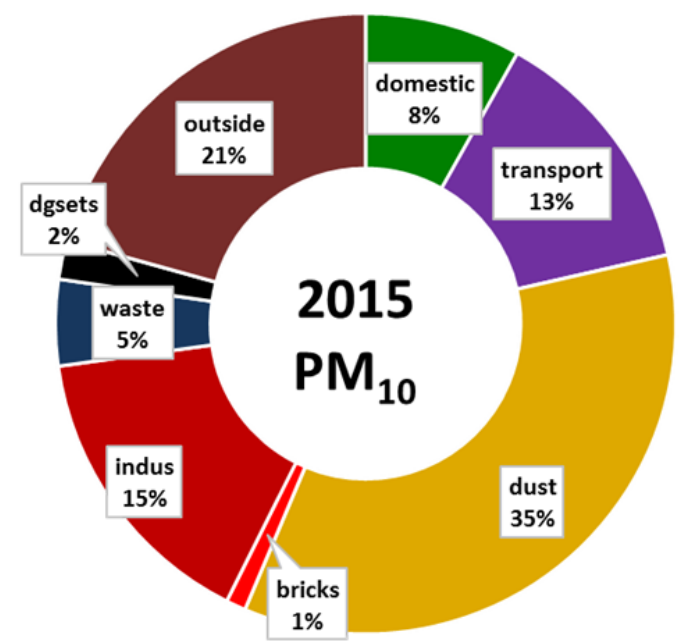

Fig. 7. Modeled source contributions to ambient $\mathrm{PM}_{2.5}$ and $\mathrm{PM}_{10}$ concentrations in 2015.

monitoring stations in the RDB region. Manual stations measure only $\mathrm{PM}_{10}, \mathrm{SO}_{2}$, and $\mathrm{NO}_{2}$ and the procedure includes manually changing and collecting the filters on average 2 times a week. The total time for sample preparation and collection, filter storage, filter processing, and reporting the measurements, takes between 2 to 7 days and this varies from state to state. The pollution control boards are now required to add $\mathrm{PM}_{2.5}$ to this chain of operations under NAMP. Based on a thumb rule designed by Central Pollution Control Board (CPCB, 2003), we estimate that RDB region requires at least 19 continuous monitoring stations to spatially and temporally represent its pollution levels.

More than $85 \%$ of the total vehicle share is $2-3-4$-wheel vehicles supporting personal transport, while buses account for $2 \%$. In the RDB region, public transportation is limited and suitable infrastructure for traffic management and mobility is largely absent. The network of private autorickshaws and cycle-rickshaws is growing, in part due to poor public transportation. Additionally, traffic congestion is a major issue, resulting in higher pollution exposure rates in the core urban area. The RDB region needs to aggressively promote public and para transportation systems, to reduce the 
current dependence on one million plus passenger vehicles and the impact of their emissions on ambient air quality. A new Special Purpose Vehicle (SPV) entitled Durg-Bhilai Urban Public Transport Society has been constituted with the purpose of managing urban transportation in the city, including setting up and organizing city-bus services, parking and traffic infrastructure, and non-motorized transport (NMT). In addition, a regional mobility plan is being developed for the Durg-Bhilai region. The city of Bhilai is due to get 115 buses as part of the program.

By 2030, the vehicle exhaust emissions are expected to remain constant, if and only if, Bharat Stage-VI fuel and vehicle standards (equivalent of Euro-VI) are introduced as planned. In April 2018, Bharat Stage-VI quality fuel was introduced in Delhi and scheduled to go national in 2020, as recommended by the Auto Fuel Policy of India. The movement of HDVs and LDVs is high in the region, because of the industrial hubs. Introduction of a green freight program, which promotes increased use of rail for movement of freight, can further supplement possible benefits of cleaner fuel and cleaner vehicles on the road. The total road network for Chhattisgarh is approximately $96,000 \mathrm{~km}$ of roads $(77,000$ surfaced, $3,000 \mathrm{~km}$ of national highways, 4,500 are state highways, and 12,500 of urban roads) (MoRTH, 2016). Less than 25\% of the Raipur city roads has access to footpaths, which are often encroached by hawkers. A sustainable urban transport policy must also include ways to reduce on-road dust re-suspension.

By 2030, the share of emissions from residential cooking and lighting is expected to decrease with an increasing share of LPG and electrification, in the urban and rural areas. In 2016-17, under the Pradhan Mantri Ujjawala Yojana (PMUY) in Chhattisgarh, more than 800,000 new LPG connections were distributed, among the low- and middle- class households in the non-urban areas. Target for 2019 is 2.5 million new connections (and 50.0 million new connections nationwide).

The RDB region lacks a comprehensive waste management system and much of the waste is routinely burnt. This practice is hard to regulate and monitor, unless a coordinated effort in made by the municipal corporations to collect and manage all the dry and the wet waste generated in the urban areas and across the region. With no new management plans underway, we estimate an increase in the share of contribution from open waste burning through 2030.

The large share of contribution from the industrial hubs, inside and outside the urban airshed, is evident from the source apportionment analysis. Upgrading the brick kiln technology from the current fixed-chimney and clampstyle baking to (for example) zig-zag kiln technology will improve their overall energy efficiency and reduce emission loads. This conversion was mandated for the kilns around Delhi airshed, to reduce their respective shares and this technological instrument should be replicated in the RDB region (GRAP, 2017). The coal-fired power plants, large industries with captive power plants, and especially the iron and steel plants in the region, need to enforce stricter environmental standards for all the criteria pollutants, to reduce their share of influence on urban air quality. In case of the power plants, environmental regulations were introduced in December 2015, to operate desulfurization units and low- $\mathrm{NO}_{\mathrm{x}}$ burners, to adhere to the new emission standards for $\mathrm{SO}_{2}$ and $\mathrm{NO}_{2}$. However, the implementation of the same is deferred to 2022 .

The commercial, residential, and infrastructure construction is one of the fastest growing sectors in the state of Chhattisgarh and in the cities like Raipur - leading to more dust at the construction sites and the roads, and higher dust shares in ambient $\mathrm{PM}_{2.5}$ and $\mathrm{PM}_{10}$ concentrations. During the severe episodes of pollution in North India, the Environment Pollution (Prevention \& Control) Authority (EPCA) for the National Capital Region, introduced the Graded Response Action Plan (GRAP), which controls the level of construction activities and commands a response system to manage operations at the construction sites. A similar system should be introduced in the RDB region to control pollution at the construction sites and for all the other sources addressed in the GRAP program.

The emissions and dispersion modeling results provided some understanding of the overall concentrations and composition of PM pollution in the region, with clear evidence of the role of industrial emissions and growing vehicle exhaust. We acknowledge key limitations in this study (a) no emission factor studies were conducted in the region for any of the sectors. While the general application of average factors with correction coefficients based on activity and meteorology yield results, there is scope for improvement; (b) no primary surveys were conducted on the consumption patterns for the industries. All the calculations are based on reports submitted by the industries; (c) monitoring data is a major bottle neck. All the comparisons made in this study are against limited manual monitoring data and data collected during receptor modeling studies. The future efforts should focus on not only improving the understanding of the emission strengths via primary measurements and their contributions to the ambient pollution levels, but also the environmental and the health impacts of air pollution in the region. Given the wide mix of sources in the RDB region and the changing trend in concentrations of pollutants other than PM, the gridded emissions inventory will be further utilized to study the role of volatile and semi-volatile organic compounds; secondary trace gases like ozone; and impact of secondary aerosols like sulfates, nitrates, and secondary organic aerosols, on physical and optical properties of PM in the region. Monitoring and modelling studies across Central India could help deconvolute the impact of regional and local emission sources and provide insights for policymaking on the issue of urban air quality.

\section{SUPPLEMENTARY MATERIAL}

Supplementary data associated with this article can be found in the online version at http://www.aaqr.org.

\section{REFERENCES}

ASI (2015). Annual survey of industries. Ministry of 
Statistics and Program Implementation, the Government of India, New Delhi, India.

Bano, S., Pervez, S., Chow, J.C., Matawle, J.L., Watson, J.G., Sahu, R.K., Srivastava, A., Tiwari, S., Pervez, Y.F. and Deb, M.K. (2018). Coarse particle $\left(\mathrm{PM}_{10-2.5}\right)$ source profiles for emissions from domestic cooking and industrial process in central India. Sci. Total Environ. 627: 1137-1145.

Burney, J. and Ramanathan, V. (2014). Recent climate and air pollution impacts on Indian agriculture. Proc. Natl. Acad. Sci. U.S.A. 111: 16319-16324.

Census-India (2012). Census of India, 2011. The Governement of India, New Delhi, India.

Chowdhury, S. and Dey, S. (2016). Cause-specific premature death from ambient $\mathrm{PM}_{2.5}$ exposure in India: Estimate adjusted for baseline mortality. Environ. Int. 91: 283-290.

CPCB (2003). Guidelines for Ambient air quality monitoring. Central Pollution Control Board, the Government of India, New Delhi, India.

CPCB (2010). Air quality monitoring, emission inventory and source apportionment study for Indian cities. Central Pollution Control Board, the Government of India, New Delhi, India.

CPCB (2016). National ambient monitoring program (NAMP). Central Pollution Control Board, the Government of India, New Delhi, India.

Deshmukh, D.K., Deb, M.K., Tsai, Y.I. and Mkoma, S.L. (2010). Atmospheric ionic species in $\mathrm{PM}_{2.5}$ and $\mathrm{PM}_{1}$ aerosols in the ambient air of eastern central India. $J$. Atmos. Chem. 66: 81.

Deshmukh, D.K., Deb, M.K., Tsai, Y.I. and Mkoma, S.L. (2011). Water soluble ions in $\mathrm{PM}_{2.5}$ and $\mathrm{PM}_{1}$ aerosols in Durg city, Chhattisgarh, India. Aerosol Air Qual. Res. 11: 696-708.

Deshmukh, D.K., Tsai, Y.I., Deb, M.K. and Mkoma, S.L. (2012). Characterization of dicarboxylates and inorganic ions in urban $\mathrm{PM}_{10}$ aerosols in the eastern central India. Aerosol Air Qual. Res. 12: 592-607.

Deshmukh, D.K., Deb, M.K. and Mkoma, S.L. (2013). Size distribution and seasonal variation of sizesegregated particulate matter in the ambient air of Raipur city, India. Air Qual. Atmos. Health 6: 259-276.

Deshmukh, D.K., Kawamura, K. and Deb, M.K. (2016). Dicarboxylic acids, $\omega$-oxocarboxylic acids, $\alpha$-dicarbonyls, WSOC, OC, EC, and inorganic ions in wintertime sizesegregated aerosols from central India: Sources and formation processes. Chemosphere 161: 27-42.

Dubey, N. and Pervez, S. (2008). Investigation of variation in ambient $\mathrm{PM}_{10}$ levels within an urban-industrial environment. Aerosol Air Qual. Res. 8: 54-64.

Giri, B., Patel, K.S., Jaiswal, N.K., Sharma, S., Ambade, B., Wang, W., Simonich, S.L.M. and Simoneit, B.R.T. (2013). Composition and sources of organic tracers in aerosol particles of industrial central India. Atmos. Res. 120-121: 312-324.

GRUMP (2015). Gridded population of the world and global rural and urban mapping project. Center for International Earth Science Information Network
(CIESIN) of the Earth Institute, Columbia University, New York, USA.

Guttikunda, S.K. and Jawahar, P. (2012). Application of SIM-air modeling tools to assess air quality in Indian cities. Atmos. Environ. 62: 551-561.

Guttikunda, S.K. and Calori, G. (2013). A GIS based emissions inventory at $1 \mathrm{~km} \times 1 \mathrm{~km}$ spatial resolution for air pollution analysis in Delhi, India. Atmos. Environ. 67: 101-111.

Guttikunda, S. and Kopakka, R. (2014). Source emissions and health impacts of urban air pollution in Hyderabad, India. Air Qual. Atmos. Health 7: 195-207.

Guttikunda, S.K. and Jawahar, P. (2014). Atmospheric emissions and pollution from the coal-fired thermal power plants in India. Atmos. Environ. 92: 449-460.

Guttikunda, S.K. and Jawahar, P. (2018). Evaluation of particulate pollution and health impacts from planned expansion of coal-fired thermal power plants in India using WRF-CAMx modeling system. Aerosol Air Qual. Res. 18: 3187-3202.

Guttikunda, S.K. and Mohan, D. (2014). Re-fueling road transport for better air quality in India. Energy Policy 68: 556-561.

Guttikunda, S.K., Goel, R. and Pant, P. (2014). Nature of Air pollution, emission sources, and management in the Indian cities. Atmos. Environ. 95: 501-510.

Guttikunda, S.K., Nishadh, K.A. and Jawahar, P. (2019). Air pollution knowledge assessments (APnA) for 20 Indian cities. Urban Climate 27: 124-141.

IIASA (2015). Greenhouse gas and air pollution interactions and synergies - South Asia program. International Institute of Applied Systems Analysis, Laxenburg, Austria.

India-APnA (2017). India Air Pollution knowledge Assessment (APnA) city program. Urban Emissions, New Delhi, India - http://urbanemissions.info.

Jain, N., Bhatia, A. and Pathak, H. (2014). Emission of air pollutants from crop residue burning in India. Aerosol Air Qual. Res. 14: 422-430.

Joshi, P.K., Kumar, M., Paliwal, A., Midha, N. and Dash, P.P. (2009). Assessing impact of industrialization in terms of LULC in a dry tropical region (Chhattisgarh), India using remote sensing data and GIS over a period of 30 years. Environ. Monit. Assess. 149: 371-376.

Kupiainen, K. (2007). Road dust from pavement wear and traction sanding. Monographs of the Boreal Environment Research, No. 26, Finnish Environmental Institute, Helsinki, Finland.

Maithel, S., Uma, R., Bond, T., Baum, E. and Thao, V.T.K. (2012) Brick kilns performance assessment, emissions measurements, \& A roadmap for cleaner brick production in India. Study report prepared by Green Knowledge Solutions, New Delhi, India.

Matawle, J.L., Pervez, S., Dewangan, S., Tiwari, S., Bisht, D.S. and Pervez, Y.F. (2014). $\mathrm{PM}_{2.5}$ chemical source profiles of emissions resulting from industrial and domestic burning activities in India. Aerosol Air Qual. Res. 14: 2051-2066.

Matawle, J.L., Pervez, S., Dewangan, S., Shrivastava, A., Tiwari, S., Pant, P., Deb, M.K. and Pervez, Y.F., (2015). 
Characterization of $\mathrm{PM}_{2.5}$ source profiles for traffic and dust sources in Raipur, India. Aerosol Air Qual. Res. 15: 2537-2548.

Matawle, J.L., Pervez, S., Deb, M.K., Shrivastava, A. and Tiwari, S. (2018). $\mathrm{PM}_{2.5}$ pollution from household solid fuel burning practices in central India: 2. Application of receptor models for source apportionment. Environ. Geochem. Health 40: 145-161.

MoRTH (2016). Road transport yearbook 2011-12. Minister of Road Transport and Highways, the Government of India, New Delhi, India.

NCEP (2015). National centers for environmental prediction. National Oceanic and Atmospheric Administration, Maryland, USA.

Nirmalkar, J., Deshmukh, D.K., Deb, M.K., Tsai, Y.I. and Sopajaree, K. (2015). Mass loading and episodic variation of molecular markers in $\mathrm{PM}_{2.5}$ aerosols over a rural area in eastern central India. Atmos. Environ. 117: 41-50.

Pandey, A.C., Murty, B.P. and Das, R.R. (2008). Some aspects of air pollution climatology of Raipur and Korba (India). Indian J. Sci. Technol. 1: 1-8.

Pandey, A., Sadavarte, P., Rao, A.B. and Venkataraman, C. (2014). Trends in multi-pollutant emissions from a technology-linked inventory for India: II. Residential, agricultural and informal industry sectors. Atmos. Environ. 99: 341-352.

Pant, P. and Harrison, R.M. (2012). Critical review of receptor modelling for particulate matter: A case study of India. Atmos. Environ. 49: 1-12.

Patel, K.S., Sahu, S., Ramteke, S., Blazhev, B., Matini, L., Yubaro, E. and Hoinkis, J. (2015). Transport pollution in India. Am. J. Anal. Chem. 6: 757-766.

Pervez, S., Bano, S., Watson, J.G., Chow, J.C., Matawle, J.L., Shrivastava, A., Tiwari, S. and Pervez, Y.F. (2018). Source profiles for $\mathrm{PM}_{10-2.5}$ resuspended dust and vehicle exhaust emissions in central India. Aerosol Air Qual. Res. 18: 1660-1672.

Pesaresi, M., Ehrlich, D., Florczyk, A.J., Freire, S., Julea, A., Kemper, T. and Syrris, V. (2016). The global human settlement layer from landsat imagery, Geoscience and Remote Sensing Symposium (IGARSS), 2016 IEEE International. IEEE, pp. 7276-7279.

Prakash, J. and Habib, G. (2018). A technology-based mass emission factors of gases and aerosol precursor and spatial distribution of emissions from on-road transport sector in India. Atmos. Environ. 180: 192-205.

Rao, P.S., Kumar, A., Ansari, M.F., Pipalatkar, P. and Chakrabarti, T. (2009). Air quality impact of sponge iron industries in central India. Bull. Environ. Contam. Toxicol. 82: 255-259.

Schipper, L., Marie-Lilliu, C. and Gorham, R. (2000). Flexing the link between transport and greenhouse gas emissions: A path for the World Bank. International Energy Agency, Paris, France.

Sharma, R., Pervez, Y. and Pervez, S. (2005). Seasonal evaluation and spatial variability of suspended particulate matter in the vicinity of a large coal-fired power station in India-Case study. Environ. Monit. Assess. 102: 1-13.

Urban Sciences (2018). Atmos - A real time air quality program in India using calibrated low-cost sensors, an initiative of Urban Sciences, Mumbai, India http://www.urbansciences.in.

USEPA (2006). Clearinghouse for Inventories \& Emissions Factors - AP 42 (fifth ed.), United States Environmental Protection Agency, Washington DC, USA.

van Donkelaar, A., Martin, R.V., Brauer, M., Hsu, N.C., Kahn, R.A., Levy, R.C., Lyapustin, A., Sayer, A.M. and Winker, D.M. (2016). Global estimates of fine particulate matter using a combined geophysical-statistical method with information from satellites, models, and monitors. Environ. Sci. Technol. 50: 3762-3772.

Wiedinmyer, C., Yokelson, R.J. and Gullett, B.K. (2014). Global emissions of trace gases, particulate matter, and hazardous air pollutants from open burning of domestic waste. Environ. Sci. Technol. 48: 9523-9530.

Zheng, T., Bergin, M.H., Johnson, K.K., Tripathi, S.N., Shirodkar, S., Landis, M.S., Sutaria, R. and Carlson, D.E. (2018). Field evaluation of low-cost particulate matter sensors in high- and low-concentration environments. Atmos. Meas. Tech. 11: 4823-4846.

Received for review, July 13, 2018

Revised, October 4, 2018

Accepted, November 23, 2018 